\title{
Swearing Expressions by Main Male and Female Characters in Night School Movie
}

\author{
Erna Elya Ningrum ${ }^{1}$, I Made Netra ${ }^{2}$, Gede Primahadi Wijaya Rajeg ${ }^{3}$ \\ ${ }^{1}$ English Department, Faculty of Arts, Udayana University \\ Denpasar, Bali, Indonesia \\ Email: elyaerna@gmail.com \\ ${ }^{2}$ English Department, Faculty of Arts, Udayana University \\ Email: imadenetra@unud.ac.id \\ ${ }^{3}$ English Department, Faculty of Arts, Udayana University \\ Email: primahadi_wijaya@unud.ac.id
}

\begin{abstract}
The use of swearing expressions used by men and women indicates a difference. This difference occurs due to the stereotypes between sex and gender. In this study, the differences in language expressions used between men and women are investigated. Language expressions that are self-referenced are sworn words as a form of expressing emotions. This study used a transformative mixed method and the data were taken from both the main male character and female character of a film entitled "Night School". Based on these data, it is concluded that different conditions and situations affect the different types and motives of the occurrence of swear words as a form of language expression between men and women.
\end{abstract}

Keyword: language-feature, gender, swear-words, film.

\section{INTRODUCTION}

Sex and gender are some of the sociolinguistics aspects of research common people still do. There is a difference in language styles in male's and female's daily lives, so there must be different characteristics that could be investigated [1]. There are various possibilities for men and women to develop different patterns of practicing a language. Most women tend to use linguistic devices to maintain and increase solidarity more often than men as it is focused on the effective function of interaction while men focused on power and status. Lastly, women are stylistically more flexible than men [2].

The habits of women's language features include lexical hedges, tag question, intonation play on declarative, use of empty adjective, precise color terms, intensifiers, hypercorrect grammar, super polite forms, avoidance of strong swear words, and emphatic stress [3]. Whereas language features used by men include minimal responses, command, and directives, swearing and taboo language, compliments, theme, and questions [4]. Women tend to talk within boundaries and pay more compliments to the opposite speaker. While men talk mindlessly, swear, use aggravated directives in delivering their opinions. Women also use more linguistic forms associated with politeness [3]. These patterns of linguistic characteristics are sometimes termed "men's style" and "women's style".

The purpose of swear words is to express the emotional state of the speaker to the other parties through communication. Swearing is considered a tactic to free people out of their anger or frustration [5]. Swearing also has a communicative function. If a speaker swears, the other people are warned of the speaker's emotional state. Men and women used swearing expressions roughly at the same rate. However, women's and men's linguistic strategies are different, depending on the situations they are in. Men used more offensive language, especially when they are in a group of the same sex. Meanwhile, women have more variations of swear words but did not use them very often.

Males are generally more aggressive than females. Male brains struggled to manage their aggressive emotions and outbursts more than female brains. Considering some studies regarding male and female aggressive behaviors, it can be claimed that male aggressiveness and the urge to use strong swearing expressions precede language [6]. Although no evidence can be found that men swear more often than women, swearing has a symbolic association with masculinity, not femininity. Kramer's (1975) studies in Coates (2004), confirm the existence of the stereotype that men do swear more than women.

This study is intended to test out one of the differences found between men's and women's language features used by both main male and female characters of Night School movie, namely swearing expressions. Night School is a 2018 American comedy movie starring Teddy Walker, a high school dropout desperately trying to earn GED, in a night school classroom run by an inspirational but also very tough teacher, Carrie Carter and directed by Malcolm D. Lee and was released by Universal Pictures on $28^{\text {th }}$ September 2018 in the United States. The movie Night School is perfect for this research as both main male and female characters uttered swearing expressions. 


\section{Problems of the Study}

Based on the background of the study above, there are two research problems, they are:

1. What is the distribution of swearing expressions produced by the main characters in Night School movies?

2. What are the motives of swearing expressions produced by the main characters in Night School movie?

\section{Aims of the Study}

Based on the problems above, the aims of the study can be identified as follows:

1. To find out the distribution of swearing expressions produced by the main characters of Night School movie.

2. To identify the motives of expressions produced by the main characters of Night School movie.

\section{RESEARCH METHOD}

This research requires a transformative mixed method [7]. The qualitative data in this research helps to expand more depths and insights into the quantitative results. This method follows the form of first reporting the quantitative results and then the qualitative results. Mixed methods are used when both quantitative and qualitative data, together, provide a better understanding of the research problem than either type by itself.

In this study, the utterances by the main characters of Night School movies are the main data of this research. The data of this study is taken from the Night School movie that can be watched from the movie portal, Netflix. Night School is a comedy movie released in 2018. The movie was directed by Malcolm D. Lee and the story of this movie is about Teddy Walker, a high school dropout trying to get his GED in a night school class run by a tough teacher, Carrie Carter. Specifically, this research discusses the utterance data spoken by the main characters of Night School. The data will be collected using observation and documentation methods. There are four steps of collecting the data such as below:

1. watch the Night School movie.

2. notes of the main characters' utterances needed for the data.

3. identify the man and woman's swearing expressions produced by the main characters of Night School movie.

4. analyzing the data collected.

\section{RESUlt AND Discussion}

\section{A. Night School Movie Summary}

Night School, a comedy genre film released on September $28^{\text {th }}, 2018$, was produced by the production house Universal Picture and Will Packer Production. This movie is directed by Malcolm D. Lee and the script of the movie is written by Kevin Hart and John Hamburg. The film is starred by Teddy Walker (Kevin Hart) and followed by Carrie (Tiffany Haddish). The film is set in a school environment with a story that tells about a group of school dropouts forced to take night classes to earn their diplomas.
The film is made from various silly scenarios or sketches patched together in telling Teddy Walker's story, who must attend a night school. In where he encounters an ensemble of misfit adult-classmates, a no-nonsense teacher, and a school principal that has a troubled past with him, to pass the GED exams he failed to sit as a teenager. The narrative unfolds with a light, but a deliberate eye on racist behavior and prejudices.

Carrie, Teddy's tough-love teacher, is introduced as a potential sparring partner for Teddy as they first encounter each another side-by-side at traffic lights. Carrie's willingness to take him into her class after their initial encounter is an incompatible act when compared with her character's previous behavior. There is a lack of consistency in this character as her point-of-view seems to fluctuate throughout the film. However, she provides a much-needed grounding among the off-the-wall nightschool students and her investment in Teddy's learning potential is vital for the narrative to advance, despite it seems unlikely.

\section{B. Descriptive Statistics of Swearing Expressions}

The utterance data regarding swearing words used as language features spoken by Teddy and Carrie are such as bitch, shit, ass, motherfucker, damn, and hell. The quantity is summarized in the table as below:

TABLE I

SUMMARY OF SWEARING EXPRESSIONS

\begin{tabular}{lcc}
\hline \hline $\begin{array}{c}\text { Swearing } \\
\text { Expressions }\end{array}$ & $\begin{array}{c}\text { QUANTITY } \\
(\text { EDDY) }\end{array}$ & $\begin{array}{c}\text { QUANTITY } \\
\text { (CARRIE) }\end{array}$ \\
\hline Bitch & 0 & 5 \\
Shit & 11 & 1 \\
Ass & 5 & 4 \\
Motherfucker & 0 & 1 \\
Damn & 5 & 0 \\
Hell & 1 & 2 \\
Total & $\mathbf{2 2}$ & $\mathbf{1 3}$
\end{tabular}

Furthermore, the number of swearing expressions uttered by the main male and female character converted into bar charts as below:

CHART 1

FREQUENCY OF SWEARING WORDS

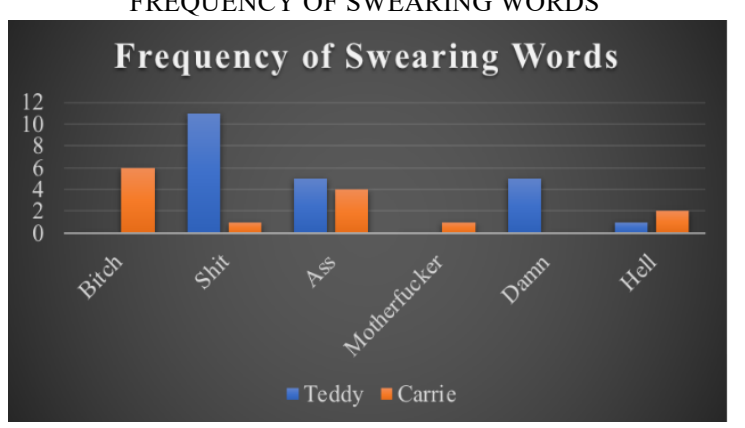

According to table 1, there are a total of 35 swear words identified used by both main characters in the Night School movie.

All of them occurred in total for 35 tokens with $62.86 \%$ are produced by the male character and $37.14 \%$ are produced by the female character. These findings suggest 
that the male character proportionally, but not absolutely, produces swear words in total more often than the female character.

As seen in Table 1, the most swear words uttered by the male character in the movie are shit and the most swear words uttered by the female character are bitch. Meanwhile, the least swear words uttered by a male character in the movie are hell and the least swear words uttered by a female character in the movie are shit and motherfucker. Furthermore, based on chart 1, the main male character is dominant for uttering swearing words. The number of swearing words uttered by the main male character more often than the main female character, but the type of swearing words uttered by the main female character holds wider variation than the main male character.

\section{Types of Swearing Expressions}

For the swear word shit uttered mostly by Teddy 11 times, the purpose in saying this swear word can be understood to be a psychological motive [8] as the condition shows that it is mostly addressed to someone's feeling. The result towards strong emotion, frustration, or anger is usually released through physical violence towards something or verbal swearing. In this condition, the swear word shit said by Teddy, are often a result of panic or a shocking situation.

For the swear word ass uttered by Teddy five times, the motive of this swearing word can also be categorized as psychological motives [8] as the condition shows that it is a result of interaction with someone's emotion. The reaction or strong emotion towards frustration or anger is usually released through physical violence towards something or verbal swearing. From the film, most of the swearing word ass is triggered by anger.

The next swear word, damn, uttered by Teddy five times, also holds a psychological motive [8] as the condition shows that it is mostly triggered by someone else's emotion. The reaction or strong emotion towards frustration or anger is usually released through physical violence towards something or verbal swearing. In this condition, mostly the swearing word damn is triggered by his emotion, anger.

The swear word hell uttered by Teddy for once is analyzed to have linguistic motives [8] as the condition shows that it holds pure motives to give stress on what people are trying to communicate. It is commonly understood that linguistic motives can also show someone's way of speaking in their daily life.

On the other hand, the swear word shit uttered by Carrie for once can be categorized as psychological motives [8] as it happened due to Carrie in her emotional rage towards her students.

For the swear word ass uttered by Carrie four times, the motive of this swearing word is categorized as psychological motives [8] as it happened mostly due to Carrie's annoyance of Teddy's, the other students, including the principal's action.

For the swear word bitch spoken by Carrie five times, the motive of this swearing word also falls into linguistic motives [8] as the condition shows that it is pure motives on linguistic subjects or to emphasize what people are trying to communicate.
For the swear word motherfucker uttered by Carrie for once, the motive of this swearing word can be categorized as psychological motives [8] as it happened mostly due to Carrie's feeling of anger towards her students.

For the swearing word hell uttered by Carrie twice, the motive of this swearing word can be categorized as psychological motives [8] as it happened mostly due to Carrie's emotion of anger and frustration towards her student's cheating action.

\section{CONCLUSION}

Various swear words are often used in making the dialogs of "Night School", whereas the male character spoke the word shit the most (11 times from a total of 22 times use of swear words), while the female character exclaimed the word bitch the most ( 5 times from a total of 13 times use of swear words).

Quantity-wise, it is safe to conclude that the male character's use of swear words goes beyond the female character's number. This serves as a result that explains how male is more emotional compared to female and the use of swear words acts as a channel for males to express their emotion.

Multiple conditions trigger the use of swear words and each condition can result from a different motive type of the swear word itself. When using swear words, the male character's motive type is mostly categorized as expletive swearing, in which the swear words are not addressed to the opposite speaker or anyone at all, but it is spoken to express emotion, the examples are anger and frustration. Meanwhile, for the female character, the use of swear words is categorized as auxiliary swearing, in which the swear words are not directed to other people, but it is uttered as her way of speaking. In understanding the motives of their swear words, both main male and female characters' motives are categorized as psychological motives, due to present condition that highly affects their emotions.

\section{REFERENCES}

[1] Cameron, D. (2005). Gender and Language Ideologies. In The Handbook of Language and Gender (pp. 447467). Blackwell Publishing Ltd.

[2] Wardhaugh, R. (2006). An Introduction to Sociolinguistics (Fifth Ed.). Blackwell Publishing Ltd.

[3] Lakoff, R. (1975). Language in Society. In Language and Woman's Place (pp. 45-80). Harper Colophon. https://doi.org.10.1017/S0047404500000051

[4] Coates, J. (2004). Women, Men, and Language (Third Ed.). Routledge.

[5] Jay, T. (2009). The Utility and Ubiquiti of Taboo Words. 4(2), 153-161. https://doi.org/10.1111/j.17456924.2009.01115.x

[6] Güvendir, E. (2015). Why are males inclined to use strong swear words more than females? An evolutionary explanation based on male intergroup aggressiveness. http://dx.doi.org/10.1016/j/langsci.2015.02.003

[7] Creswell, J. W. (2014). Research Design: Qualitative, Quantitative, and Mixed Methods Approaches (Fourth Ed.). SAGE Publications, Inc. 
[8] Karjalainen, M. (2003). Where Have All the Swearwords Gone? An Analysis of the Loss of Swearwords in Two Swedish Translation of J. D. Salingers Catcher in the Rye. 24. 